\title{
DESCRIPTION AND PREVALENCE OF Thynnascaris sp. LARVAE DOLLFUS, 1933 (NEMATODA: ANISAKIDAE) IN Plagioscion squamosissimus HECKEL, 1840 FROM VOLTA GRANDE RESERVOIR, STATE OF MINAS GERAIS, BRAZIL
}

\author{
MARTINS, M. L., ${ }^{1}$ FUJIMOTO, R. Y., ${ }^{1}$ MORAES, F. R. ${ }^{1,2}$ ANDRADE, P. M., ${ }^{1}$ \\ NASCIMENTO, A. A. ${ }^{3} \&$ MALHEIROS, E. B. ${ }^{4}$ \\ ${ }^{1}$ Laboratório de Patologia de Organismos Aquáticos, Centro de Aqüicultura, UNESP, Via Prof. Paulo Donato \\ Castellane, km 05, CEP 14870-000, Jaboticabal, SP, Brazil \\ ${ }^{2}$ Departamento de Patologia Veterinária, FCAV, UNESP, Via Prof. Paulo Donato Castellane, km 05, \\ CEP 14870-000, Jaboticabal, SP, Brazil \\ ${ }_{3}^{3}$ Departamento de Medicina Veterinária Preventiva e Reprodução Animal, FCAV, UNESP, Via Prof. Paulo Donato \\ Castellane, km 05, CEP 14870-000, Jaboticabal, SP, Brazil \\ ${ }^{4}$ Departamento de Ciências Exatas, FCAV, UNESP, Via Prof. Paulo Donato Castellane, km 05, 14870-000, \\ Jaboticabal, SP, Brazil \\ Correspondence to: M. L. Martins, Laboratório de Patologia de Organismos Aquáticos, Centro de Aqüicultura, \\ UNESP, Via Prof. Paulo Donato Castellane km 05, CEP 14870-000, Jaboticabal, SP, Brazil \\ Received May 10, 1999 - Accepted November 17, 1999 - Distributed August 31, 2000
}

(With 5 figures)

\begin{abstract}
The present work studied helminth parasites of freshwater "corvina" Plagioscion squamosissimus from Volta Grande Reservoir, MG, Brazil. Sixty eight fishes with averages of $25.2 \mathrm{~cm}$ length and 180.9 g weight were collected with net, bimonthly from December 1995 thru December 1996. Parasites were carefully removed from their cysts that were present in the intestinal mesentery. Specimens were fixed in AFA $65^{\circ} \mathrm{C}$ and preserved in alcohol $70 \%$ with 5\% of glicerine. In camera lucida 21 nematodes were drawned after clarification with acetic acid or Amann lactophenol. Nematode larvae were identified as Thynnascaris sp. (Nematoda: Anisakidae). From examined fishes 30 out of 68 presented nematode larvae with a prevalence of $44.1 \%$. The average number of parasites per host was 0.0 to 13.8 and mean intensity of 0.0 to 16.0. Statistical analysis according to Fisher's Exact Test showed that these infections were dependent on the pluviosity and air temperature
\end{abstract}

Key words: Nematoda, Thynnascaris larvae, Plagioscion squamosissimus, seasonality, prevalence.

\section{RESUMO}

Descrição e Prevalência de larvas de Thynnascaris sp. Dollfus, 1933 (Nematoda: Anisakidae) em Plagioscion squamosissimus Heckel, 1840 Proveniente do Reservatório de Volta Grande, Estado de Minas Gerais, Brasil

O presente trabalho teve por objetivo o estudo da helmintofauna da corvina de água doce Plagioscion squamosissimus, do reservatório de Volta Grande, MG, Brasil. Foram colhidos 68 peixes com comprimento médio de $25,2 \mathrm{~cm}$ e peso médio de $180,9 \mathrm{~g}$, com rede de espera, bimestralmente no período de dezembro de 1995 a dezembro de 1996. Os parasitos foram cuidadosamente retirados de seus cistos que estavam aderidos ao mesentério intestinal. Os espécimes foram fixados em $\mathrm{AFA}$ a $65^{\circ} \mathrm{C}$ e conservados em álcool $70^{\circ} \mathrm{GL}$ contendo $5 \%$ de glicerina. Após diafanização com ácido acético ou lactofenol de Amann, 21 nematóides foram desenhados em câmara clara. As larvas foram identificadas como Thynnascaris sp. (Nematoda: Anisakidae). Das 68 corvinas examinadas, 30 estavam infectadas por esses parasitos com uma prevalência de $44,1 \%$. O número médio de parasitos por hospedeiro foi 
de 0 a 13,8 e a intensidade média, de 0 a 16. A análise estatística, de acordo com o Teste Exato de Fisher, mostrou que a sazonalidade foi dependente da pluviosidade e temperatura do ar.

Palavras-chave: Nematoda, larvas de Thynnascaris, Plagioscion squamosissimus, sazonalidade, prevalência.

\section{INTRODUCTION}

Anisakid nematodes are found parasitizing various species of Brazilian fishes. Still, one of the first work to be written on them was Contracaecum spiculigerum from Pimelodella lateristriga and Acestrorhamphus sp. (Travassos et al., 1928). The worm may infect piscivorous birds, mammals and fish. Commonly the larval stage is found in fish (Vidal-Martinez et al., 1994). Contracaecum was related from mesentery of the intestine and estomach of Astyanax sp. (Kloss, 1966); C. fortalezae from Scomberomorus cavalla and S. maculatus (Klein, 1973), and Contracaecum sp from Serrasalmus altuvei (Leão et al., 1991).

In marine environment $C$. fortalezae was reported from Harengula clupeola (Guimarães \& Cristofaro, 1974) and Contracaecum sp. from Macrodon ancylodon (Vicente \& Fernandes, 1978). Other species such as C. epinepheli, C. seriolae, C. paralichthydis, C. legendrei, C. scomberomori were found in Japan (Yamaguti, 1941a,b; Kagei et al., 1970; Moravec et al., 1985). Their presence in the cod liver was studied by Rokicki et al. (1993).

Prevalence studies in brazilian fishes showed $64.4 \%$ in Hoplias malabaricus (Fabio, 1982); $32.2 \%$ of fishes from Mogi Guassu River (Kohn \& Fernandes, 1987); 100\% in Crenicichla lepidota from Salto Osório Reservoir, Parana State (Kohn et al., 1988); 68.9\% in Salminus maxillosus, Serrasalmus nattereri, S. marginatus and Brycon hilarii (Rego \& Vicente, 1988). Valtonen et al. (1988) related C. osculatum showing $20 \%$ prevalence in Salmo salar and Myoxocephalus scorpius, $16 \%$ in Lota lota and 15\% in Gadus morhua. Controversy about taxonomy of Thynnascaris, Contracaecum and Hysterothylacium remain unsettled. Records of Thynnascaris larvae (Wooten, 1978; Hurst, 1984; Arthur \& Arai, 1980) and Hysterothylacium sp larvae (Vicente et al., 1985; Moravec et al., 1985; Moravec \& Sei, 1988; Koie, 1993; Moravec \& Nagasawa, 1998; González, 1998) were observed.
In the present work, the authors made a description of Thynnascaris sp. larvae Dollfus, 1933 (Nematoda: Anisakidae) from Plagioscion squamosissimus collected in the Volta Grande Reservoir, MG, Brazil. Prevalence and seasonality were evaluated.

\section{MATERIAL AND METHODS}

Sixty eight specimens of corvina, Plagioscion squamosissimus Heckel, 1840 (Sciaenidae) were collected bimonthly with the aid of a net, during a period of one year (12/1995 to 12/1996). This work was developed in the Volta Grande Reservoir, MG, Brazil which presents a flooded area of 195 $\mathrm{km}^{2}$. Nematode larvae were carefully collected from the intestinal mesentery, dissecated from their cysts and fixed in AFA $65^{\circ} \mathrm{C}$ for posterior preservation in alcohol $70 \%$ with $5 \%$ of glicerine. For the observation of the internal structures acetic acid or Amann lactophenol were employed. Some larvae were quicklly imersed in lugol solution. Twenty one specimens were measured $(\mathrm{mm})$ and drawn with the help of a camera lucida and a light microscope. Prevalence (number of infected host/ number of examined host) and mean intensity (total number of parasite/number of infected host) were calculated according to Bush et al. (1997). To determine if there were significant differences among the prevalence in each month, Fisher's Exact Test was performed according to Pimentel Gomes (1985).

\section{RESULTS}

\section{Thynnascaris sp. Dollfus, 1933 (Nematoda: Anisakidae)}

Elongated larvae with total length of 2,544 $\mathrm{mm}(2,169$ to 2,782$)$ and maximun width of 86.2 $\mathrm{mm}$ (80.6 to 104.8$)$. Anterior end presenting two pairs of papillae with a tooth $3.4 \mathrm{~mm}$ (3.2 to 4.0 ) long. Cylindrical esophagus measuring $249.5 \mathrm{~mm}$ (168.1 to 276.6) length and $21.3 \mathrm{~mm}$ (19.1 to 23.4) width. Esophagean bulb slightly enlarged with 27.3 
mm (19.1 to 40.4) width. Nerve ring $129.2 \mathrm{~mm}$ (95.7 to 146.8 ) and excretory pore $135.5 \mathrm{~mm}$ (85.1 to 148.9) from the anterior extremity. Very long ventricular appendix pointed to the posterior extremity measuring $765.5 \mathrm{~mm}(564.5$ to $1,032.2)$ length. A small and enlarged intestinal caecum pointed to the anterior extremity measuring 28.5 $\mathrm{mm}$ (21.3 to 42.5$)$ in length was observed. Conical tail with $71.1 \mathrm{~mm}$ (63.8 to 82.9) long. Caudal process lacking spines (Figs. 3 to 5).

\section{Remarks}

Many times the Contracaecum genus as a synonym of the Hysterothylacium (Bristow \& Berland, 1991) was observed although these two genera are separated in some identification Keys. If the excretory pore is situated subventrally in the mouth cavity it belongs to Contracaecum, but if its situated near to the nerve ring it belongs to Hysterothylacium (Vicente et al., 1985). To confirm these disagreement some authors identified $C$. fortalezae without considering the excretory pore (Klein, 1973; Vicente \& Fernandes, 1978) or Yamaguti (1941a, b). Guimarães \& Cristofaro (1974) described the excretory pore distant from the anterior end in C. incurvum, C. histiophori, C. marinum, C. pagrosoni, C. gracile, C. saba and $C$. fortalezae. For this reason, in the present paper the authors identified the nematode larvae by the priority law according to Hartwitch (1974).

The present description differs from the cited literature in the total length, width and other characters that are smaller than in the other specimens. Ventricular appendix presented increased length when compared to Kagei et al. (1970), Klein (1973), Guimarães \& Cristofaro (1974), Vicente \& Fernandes (1978) and Moravec et al. (1985), but decreased length when compared to Moravec et al. (1985) and Rokicki et al. (1993). Intestinal caecum showed shorter length than described by Moravec et al. (1985), Moravec \& Sei (1988) and Hurst (1984). From the paper of Yamaguti (1941a, b) it was not possible to make any comparisons in spite of so different morphology and larval stages. Distance of the nerve ring and excretory pore from anterior extremity presented lower measurements than related by Moravec et al. (1985) and Moravec \& Sei (1988) (Table 2). To confirm the species of parasite it will be necessary to collect definitive hosts that will encorage future study.

\section{Prevalence}

Thirty out of sixty eight examined fishes presented nematode larvae in the internal organs showing a prevalence of $44.1 \%$. The total of 354 larvae were collected from the intestinal mesentery. December 1995 and October 1996 showed higher prevalence of nematodes, respectively $85.7 \%$ and $80.0 \%$ than observed in February, April and December 1996 , respectively $63.6 \%, 6.7 \%$ and $66.7 \%$. In June and August the presence of parasite (Table 1) was not related. These results showed strong relation between temperature and pluviosity in the reservoir region. When the plotted data are put together prevalence related to elevated temperature and pluviosity is evident (Figs. 1a, b; 2a, b). However, mean intensity was 13.8 and 10.6 in February and October 1996 and just one specimen of nematode larvae was collected in April 1996. An interesting fact that may be observed is the great number of infected fishes in December 1995, February, October and December 1996 as shown in Table 1. Statistical analysis according to Fisher's Exact Test showed that these infections were dependent on the pluviosity and air temperature.

\section{DISCUSSION}

The first record found in the literarature was Contracaecum sp and Amplicaecum sp larvae in brazilian fishes (Travassos et al., 1928). Years later reports of Contracaecum sp. in the visceral mesentery in traíra (Hoplias malabaricus) showed a prevalence of $64.4 \%$ and mean intensity of 5.3 (Fabio, 1982). Other observed prevalences of nematode larvae in brazilian native fishes were $29.2 \%$ in Salminus maxillosus (Kohn \& Fernandes, 1987); $100 \%$ (Kohn et al., 1988); $33.3 \%$ in $S$. maxillosus, $100 \%$ Serrasalmus nattereri, $100 \%$ S. marginatus and $100 \%$ Brycon hilarii (Rego \& Vicente, 1988).

According to our findings a total prevalence of $44.1 \%$ was not higher than that of other studies, but when analized and considered per month, the present work showed up to $85.7 \%$ values. Lower prevalences (20\%) was also reported of $C$. osculatum from the Baltic Sea (Valtonen et al., 1988).

The authors demonstrated mean intensity of 6.0 that was thus different from the present study (16.0). 

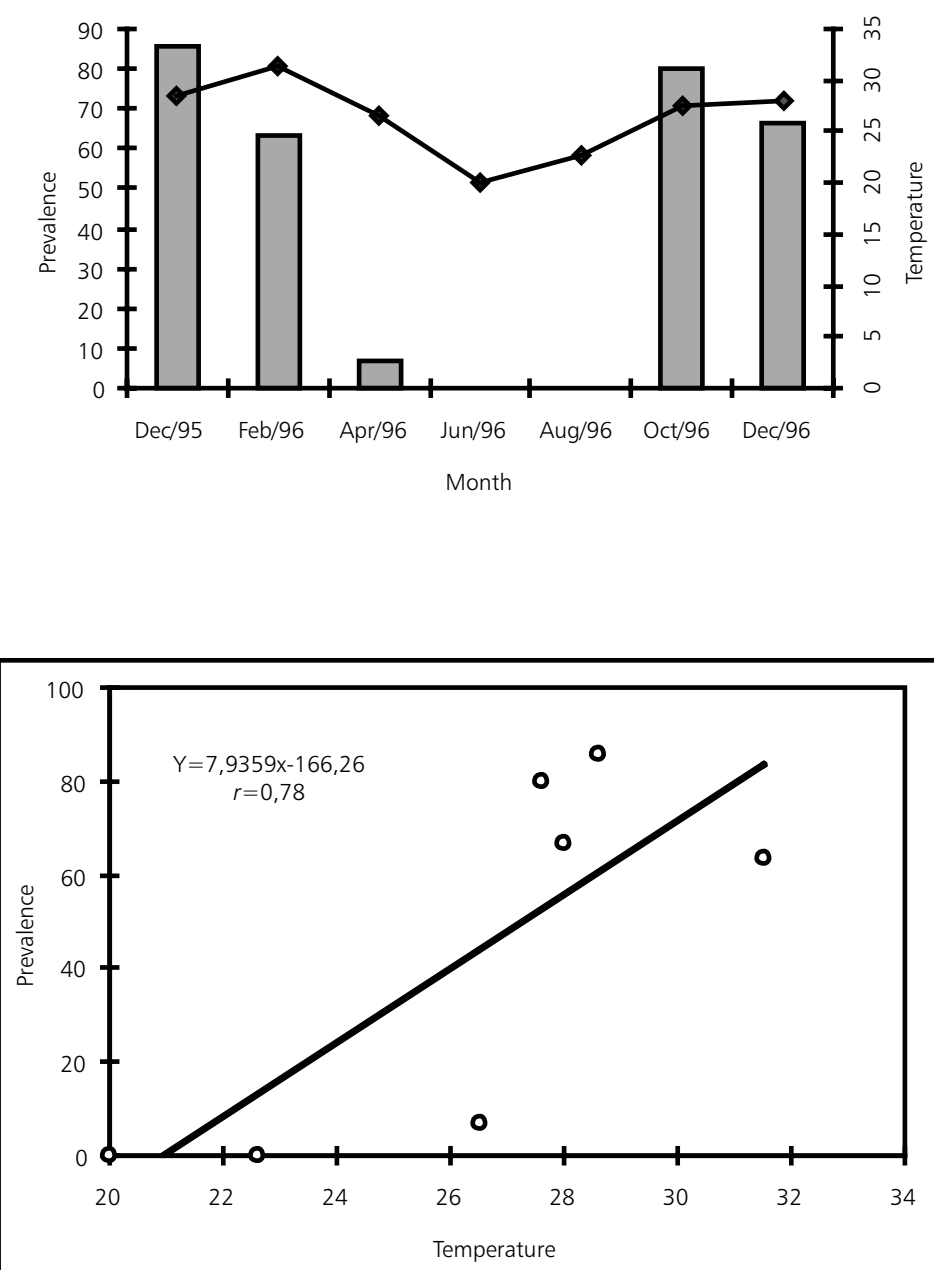

Fig. 1 - (a) Prevalence of Thynnascaris sp. larvae from P. squamosissimus related to temperature. Bar- prevalence (\%); line- air temperature $\left({ }^{\circ} \mathrm{C}\right)$. (b) Positive correlation between the data.

TABLE 1

Mean values of total length and weight of fishes, number of parasites and prevalence in $P$. squamosissimus, during a period of December 1995 to December 1996. Volta Grande Reservoir, State of Minas Gerais, Brazil.

\begin{tabular}{|c|c|c|c|c|c|c|}
\hline Month & CF/IF & FL (cm) & $\mathbf{W}(\mathrm{g})$ & TNP & MI (V) & $\mathrm{P}(\%)$ \\
\hline Dec/95 & $07 / 06$ & 19.3 & 82.1 & 42.0 & $7.0(3-11)$ & 85.7 \\
\hline Feb/96 & $11 / 07$ & 25.9 & 180.2 & 111.0 & $15.8(2-65)$ & 63.6 \\
\hline Apr/96 & $15 / 01$ & 33.5 & 443.2 & 1.0 & 1.0 & 6.7 \\
\hline Jun/96 & $09 / 0$ & 37.9 & 727.0 & 0.0 & 0.0 & 0.0 \\
\hline Aug/96 & $05 / 0$ & 25.3 & 177.2 & 0.0 & 0.0 & 0.0 \\
\hline Oct/96 & $15 / 12$ & 26.3 & 195.0 & 163.0 & $13.6(1-23)$ & 80.0 \\
\hline Dec/96 & $06 / 04$ & 29.5 & 265.8 & 35.0 & $8.7(1-17)$ & 66.7 \\
\hline
\end{tabular}

(CF/IF) collected fish/infected fish; (FL) fish length; (W) fish weight; (TNP) total number of collected parasite; (MI) mean inten: and variation $(\mathrm{V}) ;(\mathrm{P})$ prevalence. 

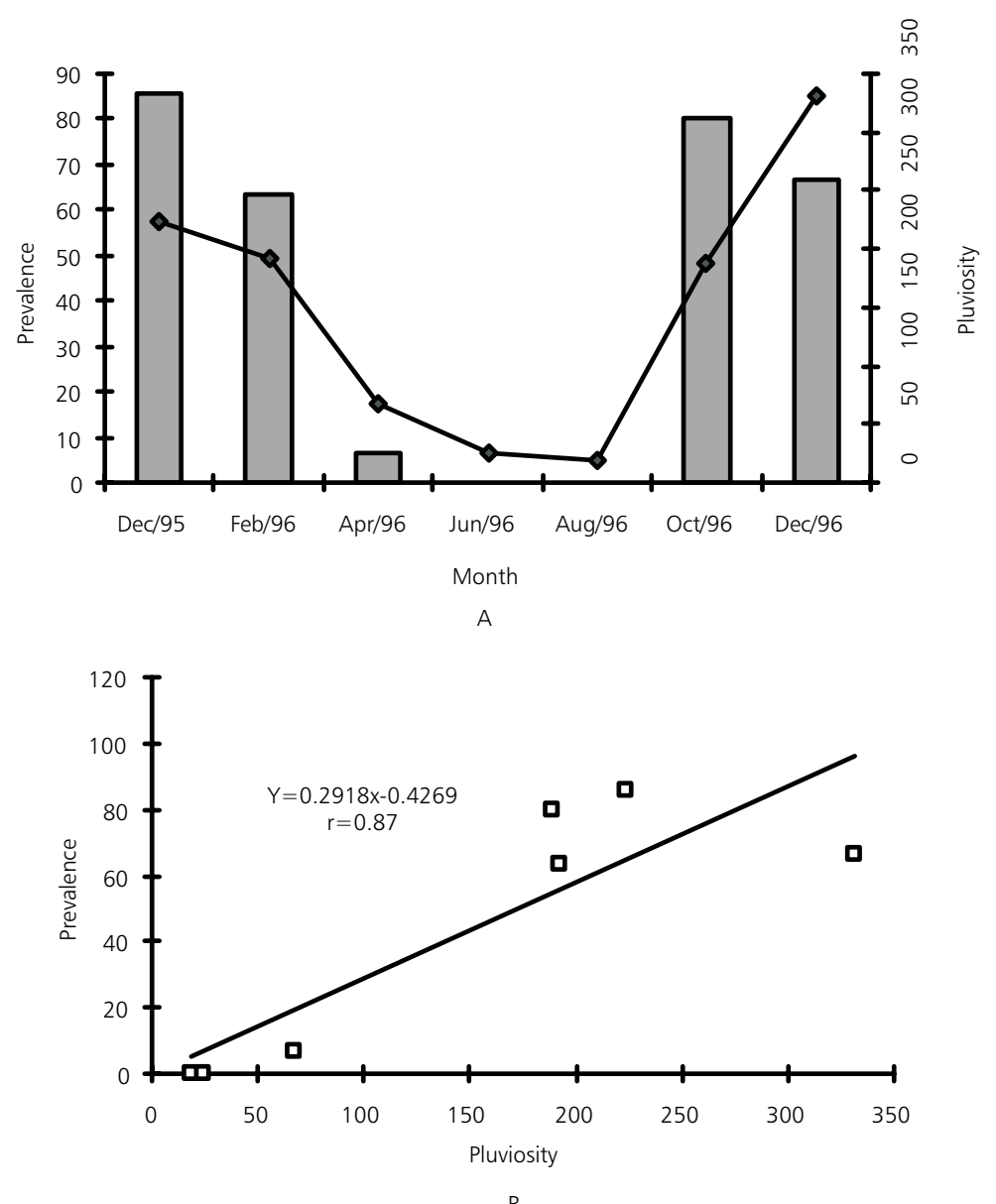

Fig. 2 - (a) Prevalence of Thynnascaris sp. larvae from P. squamosissimus related to pluviosity. Bar- prevalence (\%); linepluviosity (mm). (b) Positive correlation between the data.

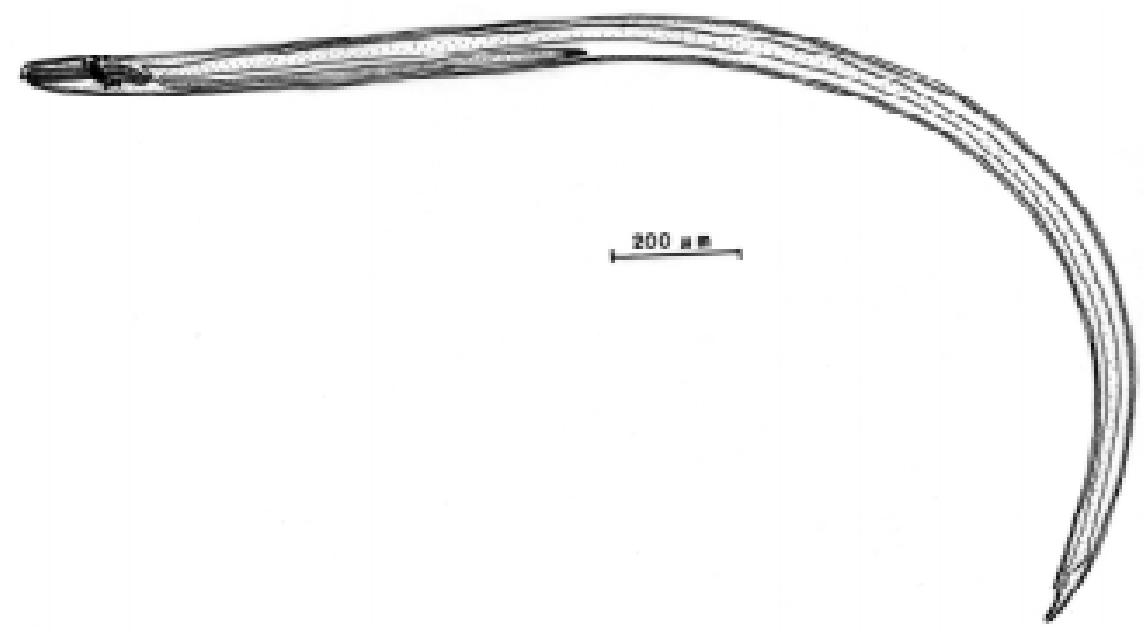

Fig. 3 - Thynnascaris sp larvae from P. squamosissimus. Note ventricular appendix length. 


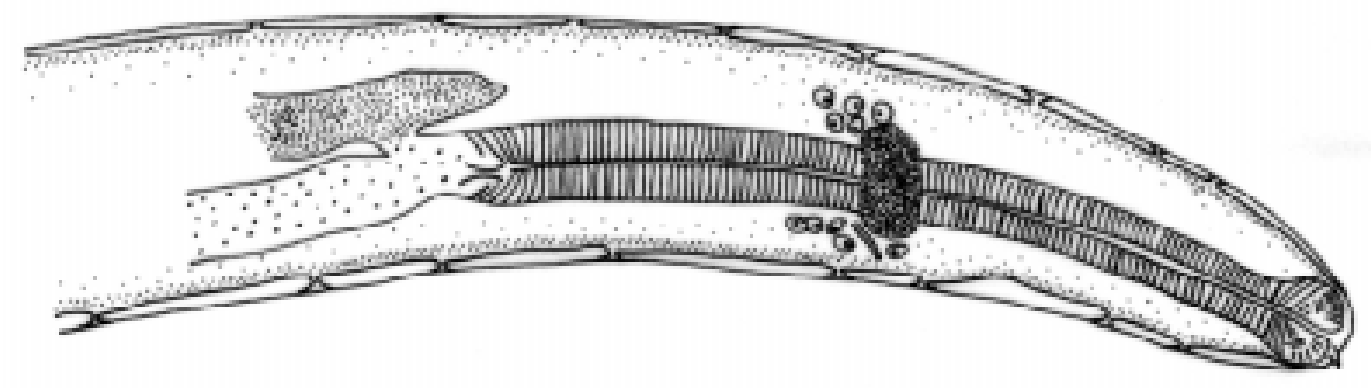

$500 \mu \mathrm{m}$

Fig. 4 - Esophagus, nerve ring and excretory pore of Thynnascaris sp. larvae in molt stage.

TABLE 2

Comparative values $(\mathrm{mm})$ of anisakid nematodes larvae and their authors with the present work.

\begin{tabular}{|c|c|c|c|c|c|c|}
\hline Characters & $\begin{array}{l}\text { Contracaecu } \\
\text { m Kagei et al. } \\
\quad(1970)\end{array}$ & $\begin{array}{c}\text { Contracaecum } \\
\text { Rokicki et al. } \\
(1993)\end{array}$ & $\begin{array}{c}\text { Hysterothylacium } \\
\text { Moravec et al. } \\
(\mathbf{1 9 8 5})\end{array}$ & $\begin{array}{c}\text { Hysterothylacium } \\
\text { Moravec \& Sei } \\
(1988)\end{array}$ & $\begin{array}{c}\text { Thynnascaris } \\
\text { Hurst } \\
(1984)\end{array}$ & $\begin{array}{l}\text { Thynnascaris } \\
\text { present work }\end{array}$ \\
\hline $\begin{array}{c}\text { Intestinal } \\
\text { caecum }\end{array}$ & $\begin{array}{c}180 \\
(130-240)\end{array}$ & $\begin{array}{c}761 \\
(561-935)\end{array}$ & $\begin{array}{l}* 476 \\
* * 530\end{array}$ & $\begin{array}{c}503 \\
(360-510)\end{array}$ & $(260-800)$ & $\begin{array}{c}28.5 \\
(21.3-42.5)\end{array}$ \\
\hline $\begin{array}{l}\text { Ventricular } \\
\text { appendix }\end{array}$ & $\begin{array}{c}5,350 \\
(3,060-7,900) \\
\end{array}$ & $\begin{array}{c}1,163 \\
(891-1,540) \\
\end{array}$ & $\begin{array}{l}* 408 \\
* * 476 \\
\end{array}$ & $(4,760-5,690)$ & $(280-720)$ & $\begin{array}{c}765.5 \\
(564.5-1,032.2) \\
\end{array}$ \\
\hline Nerve ring ${ }^{\mathrm{a}}$ & - & $(264-361)$ & $\begin{array}{l}* 326 \\
* * 313\end{array}$ & $(218-261)$ & - & $\begin{array}{c}129.2 \\
(95.7-146.8)\end{array}$ \\
\hline $\begin{array}{c}\text { Excretory } \\
\text { pore }^{\mathrm{a}}\end{array}$ & $\begin{array}{l}\text { near to nerve } \\
\text { ring }\end{array}$ & $\begin{array}{l}\text { opens at the } \\
\text { head }\end{array}$ & $\begin{array}{l}* 353 \\
* * 367 \\
\end{array}$ & $(231-326)$ & - & $\begin{array}{c}135.5 \\
(85.1-148.9) \\
\end{array}$ \\
\hline Length & $\begin{array}{c}16,100 \\
(11,200- \\
21,400)\end{array}$ & $\begin{array}{c}18,377 \\
(11,319- \\
22,534)\end{array}$ & $\begin{array}{c}* 8,640 \\
* * 9,810\end{array}$ & $(8,230-10,200)$ & $\begin{array}{l}(3,700- \\
12,300)\end{array}$ & $\begin{array}{c}2,544 \\
(2,169-2,782)\end{array}$ \\
\hline Width & $\begin{array}{c}580 \\
(410-820)\end{array}$ & $\begin{array}{c}500 \\
(385-693)\end{array}$ & $\begin{array}{l}* 163 \\
* * 218\end{array}$ & $(258-340)$ & $(100-290)$ & $\begin{array}{c}86.2 \\
(80.6-104.8)\end{array}$ \\
\hline Tail $^{\mathrm{b}}$ & $\begin{array}{c}190 \\
(130-290)\end{array}$ & $\begin{array}{c}190 \\
(95-275)\end{array}$ & $\begin{array}{l}* 120 \\
* * 190\end{array}$ & $(96-138)$ & $(90-190)$ & $\begin{array}{c}71.1 \\
(63.8-82.9)\end{array}$ \\
\hline
\end{tabular}

* male measurement; ** female measurement.

${ }^{a}$ distance from the anterior end.

${ }^{\mathrm{b}}$ distance of anus to the posterior end.

One of the higher prevalences was observed in T. adunca larvae (100\%) (Wootten, 1978), $H$. aduncum (Bristow \& Berland, 1991; González, 1998) which presented $66.1 \%$ and $79.0 \%$, respectively, in the intestinal mesentery (mean intensity of 44.5 and 4.9 , respectively). In the present work mean intensity was 16.0. Studies on seasonality of Anisakid larvae are scarce.

Wooten (1978) and Valtonen et al. (1988), respectively, observed a great distribution of $T$. adunca and C. osculatum related to lower length classes of the collected fishes in the North Sea and Baltic Sea. However, the present work is the first record on seasonality related to temperature and pluviosity. In $P$. squamosissimus it was not observed the relation between the weight or length of fish.

Nevertheless, higher prevalence of larvae was observed with increased temperature and pluviosity during the year (Figs. 1 and 2). 

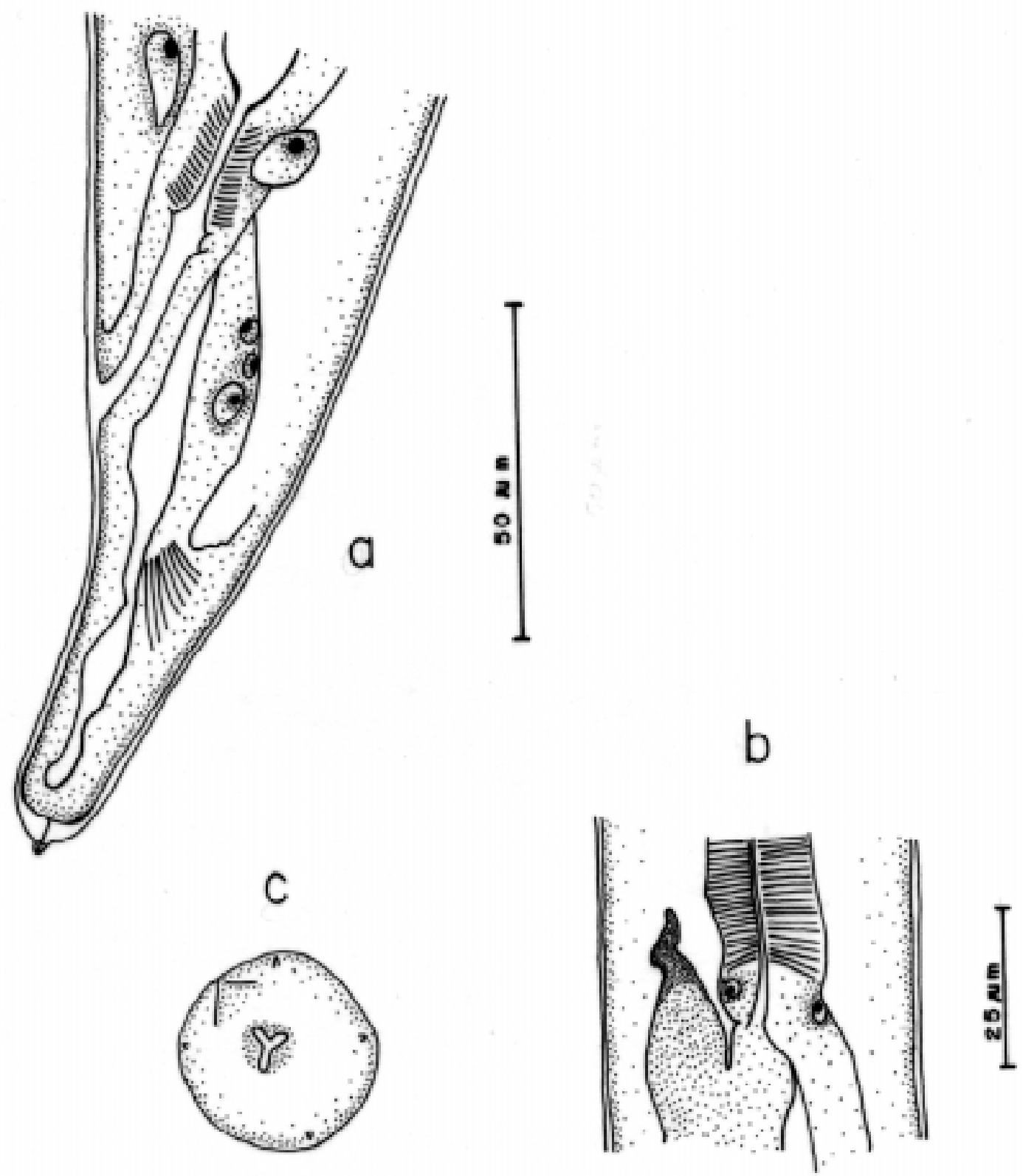

$10 \mathrm{xm}$

Fig. 5 - (a) Tail of larvae in molt stage; (b) intestinal caecum; (c) apical view of the anterior end of Thynnascaris sp. larvae.

Acknowledgments - We are gratefull to Companhia Energética de Minas Gerais (CEMIG, MG by the finnancial support. To José Hairton Tebaldi and Hermes Ascari (Departamento de Medicina Veterinária Preventiva e Reprodução Animal, FCAV, UNESP, Jaboticabal, SP) for technical aid. To Gastão Reis for the correction of the translation of the manuscript.

\section{REFERENCES}

ARTHUR, J. R. \& ARAI, H. P., 1980, Studies on the parasites of Pacific herring (Clupea harengus pallasi Valenciennes) a prelimimary evaluation of parasites as indicators of geographical origin for spawning herring. Can. J. Zool., 58: 521-527. 
BRISTOW, G. A. \& BERLAND, B., 1991, A report on some metazoan parasites of wild marine salmon (Salmon salar L.) from the west coast of Norway with comments on their interactions with farmed salmon. Aquaculture, 98 : 311-318.

BUSH, A. O., LAFFERTY, K. D., LOTZ, J. M. \& SHOSTAK, A. W., 1997, Parasitology meets ecology on its own terms: Margolis et al. revisited. J. Parasitol., 83(4): 575583.

FABIO, S. P., 1982, Sobre alguns nematoda parasitos de Hoplias malabaricus. Arq. Univ. Fed. Rur. Rio de Janeiro, 5(2): 179-186.

GONZÁLEZ, L., 1998, The life cycle of Hysterothylacium aduncum (Nematoda: Anisakidae) in Chilean marine farms. Aquaculture, 162: 173-186.

GUIMARÃES, J. F. \& CRISTOFARO, R., 1974, Contribuição ao estudo da fauna helmintológica de peixes do estado da Bahia. Atas Soc. Biol. Rio de Janeiro, 17(2): 81-85.

HARTWICH, G., 1974, Keys to the genera of the Ascaridoidea. In: R. C. Anderson, A. G. Chabaud \& S. Willmot (eds.), CHI Keys to the Nematodes Parasites of Vertebrates. Commonwealth Agricultural Bureaux, Fanham Royal, Bucks, 2: 1-15.

HURST, R. J., 1984, Marine invertebrate hosts of New Zealand Anisakidae (Nematoda). New Zealand J. Mar. Freshwater Res., 18: 187-196.

KAGEI, N., SAKAGUCHI, Y., KATAMINE, D. \& IKEDA, Y., 1970, Studies on Anisakid Nematoda (Anisakinae). II. Contracaecum sp. (type V of Yamaguti) found in marine fishes (Appendix: List and Main Features of the larvae of Contracaecum spp. Recorded from marine fishes and Squids caught off the Japan and its Offshore Island). Bull. Inst. Publ. Hlth, 19(4): 243-251.

KLEIN, V. L. M., 1973, Helmintos parasitos das espécies Scomberomus cavalla (Cuvier) e Scomberomus maculatus (Mitchill) do litoral Cearense. Contracaecum fortalezae sp. N. (Nematoda, Ascaroidea). Mem. Inst. Oswaldo Cruz, Rio de Janeiro, 71(1/2): 199-202.

KLOSS, G. R., 1966, Helmintos parasitos de espécies simpátricas de Astyanax (Pisces, Characidae). 1. Papéis Dep. Zool., São Paulo, 18(17): 190-219.

KOHN, A. \& FERNANDES, B. M. M., 1987, Estudo comparativo dos helmintos parasitos de peixes do rio Mogi Guaçu, coletados nas excursões realizadas entre 1927 e 1985. Mem. Inst. Oswaldo Cruz, Rio de Janeiro, 82(4): 483-500.

KOHN, A., FERNANDES, B. M. M., PIPOLO, H. V. \& GODOY, M. P., 1988, Helmintos parasitos de peixes das usinas hidrelétricas da Eletrosul (Brasil). II. Reservatórios de Salto Osório e Salto Santiago, Bacia do rio Iguaçu. Mem. Inst. Oswaldo Cruz, Rio de Janeiro, 83(3): 299303.

KOIE, M., 1993, Aspects of the life cycle and morphology of Hysterothylacium aduncum (Rudolphi, 1802) (Nematoda, Ascaridoidea, Anisakidae). Can. J. Zool., 71: 12891296.
LEÃO, E. L. M., LEITE, R. G., CHAVES, P. T. C. \& FERRAZ, E., 1991, Aspectos da reprodução, alimentação e parasitofauna de uma espécie de piranha, Serrasalmus altuvei, Ramirez, 1965 (Pisces, Serrasalmidae) do baixo Rio Negro. Rev. Brasil. Biol., 51(3): 545-553.

MORAVEC, F., NAGASAWA, K. \& URAWA, S., 1985, Some fishes nematodes from fresh waters in Hokkaido, Japan. Folia Parasitologica, 32: 305-316.

MORAVEC, F. \& SEI, O., 1988, Nematodes of freshwater fishes from north Vietnam. Part 3. Cosmocercoidea, Seuratoidea, Atractoidea, Heterakoidea and Ascaridoidea. Vést. Cs. Spolec. Zool., 52: 250-265.

MORAVEC, F. \& NAGASAWA, K., 1998, Hysterothylacium japonicum sp. n. (Nematoda: Anisakidae) from the rare marine fish Trachipterus ishikawai in Japan. Acta Parasitologica, 43: 39-42.

PIMENTEL GOMES, F., 1985, Curso de Estatística Experimental. Livraria Nobel, Piracicaba, 11 ${ }^{\mathrm{a}}$ Ed., 466p.

REGO, A. A. \& VICENTE, J. J., 1988, Excursão ciêntifica à zona do Pantanal, Estado de Mato Grosso, para coletas de helmintos. Ciênc. Cult., 40(1): 65-69.

ROKICKI, J., VALTER, E. D. \& MYJAK, P., 1993, Contracaecum osculatum (Nematoda, Anisakidae) in cod, Gadus morhua L. from the Polish coast of the Baltic. Acta Parasitologica, 38(1): 33-35.

TRAVASSOS, L., ARTIGAS, P. \& PEREIRA, C., 1928, Fauna Helmintológica dos peixes de água doce do Brasil. Arch. Inst. Biol., São Paulo, 1: 1-81.

VALTONEN, E. T., FAGERHOLM, H.-P. \& HELLE, E., 1988, Contracaecum osculatum (Nematoda: Anisakidae) in fish and seals in Bothnian Bay (Northeastern Baltic Sea). Int. J. Parasitol., 18(3): 365-370.

VICENTE, J. J. \& FERNANDES, G. L., 1978, Contribuição ao conhecimento dos helmintos de Bagre bagre (Linnaeus, 1766) Fowler, 1841 e de Macrodon ancylodon (Bloch, 1801) Jordan, Evermann \& Clark, 1930, no litoral da ilha de São Luís, estado do Maranhão, Brasil. Bol. Lab. Hidrobiol., 2(1): 91-96.

VICENTE, J. J., RODRIGUES, H. O. \& GOMES, D. C., 1985, Nematóides do Brasil. Primeira parte: Nematóides de peixes. Atas Soc. Biol. Rio de Janeiro, 25: 1-79.

VIDAL-MARTINEZ, V. M., OSORIO-SARABIA, D. \& OVERSTREET, R. M., 1994, Experimental infection of Contracaecum multipapillatum (Nematoda: Anisakinae) from Mexico in the domestic cat. J. Parasitol., 80(4): 576-579.

YAMAGUTI, S., 1941a, Studies on the helminth fauna of Japan. Part 9. Nematodes of fishes, I. Jap. J. Zool., 9(3): 338-349.

YAMAGUTI, S., 1941b, Studies on the helminth fauna of Japan. Part 33. Nematodes of fishes, II. Jap. J. Zool., 9(3): $358-369$.

WOOTEN, R., 1978, The occurrence of larval anisakid nematodes in small gadoids from scottish waters. J. Mar. Biol. Ass. U.K., 58: 347-356. 